\title{
Incorporation of Adenovirus in Calcium Phosphate Precipitates Enhances Gene Transfer to Airway Epithelia In Vitro and In Vivo
}

\author{
Al Fasbender, ${ }^{\dagger}$ John H. Lee, Robert W. Walters, Thomas O. Moninger, Joseph Zabner, and Michael J. Welsh \\ Howard Hughes Medical Institute and Departments of Internal Medicine and Physiology and Biophysics, University of Iowa College of \\ Medicine, Iowa City, Iowa 52242
}

\begin{abstract}
Adenovirus (Ad)-mediated gene transfer to airway epithelia is inefficient because the apical membrane lacks the receptor activity to bind adenovirus fiber protein. Calcium phosphate $(\mathrm{CaPi})$ precipitates have been used to deliver plasmid DNA to cultured cell lines. However, such precipitates are not effective in many primary cultures or in vivo. Here we show that incorporating recombinant adenovirus into a $\mathrm{CaPi}$ coprecipitate markedly enhances transgene expression in cells that are resistant to adenovirus infection. Enhancement requires that the virus be contained in the precipitate and viral proteins are required to increase expression. Ad: $\mathrm{CaPi}$ coprecipitates increase gene transfer by increasing fiber-independent binding of virus to cells. With differentiated cystic fibrosis (CF) airway epithelia in vitro, a 20-min application of $\mathrm{Ad}$ : $\mathrm{CaPi}$ coprecipitates that encode $\mathrm{CF}$ transmembrane conductance regulator produced as much $\mathrm{CF}$ transmembrane conductance regulator $\mathrm{Cl}^{-}$current as a 24-h application of adenovirus alone. We found that $\mathrm{Ad}: \mathrm{CaPi}$ coprecipitates also increased transgene expression in mouse lung in vivo; importantly, expression was particularly prominent in airway epithelia. These results suggest a new mechanism for gene transfer that may be applicable to a number of different gene transfer applications and could be of value in gene transfer to CF airway epithelia in vivo. $(J$. Clin. Invest. 1998. 102:184-193.) Key words: adenovirus • cystic fibrosis - gene transfer • airway epithelia • calcium phosphate
\end{abstract}

\section{Introduction}

A common problem in the development of gene therapy is the limited efficiency of gene transfer by viral and nonviral vectors. This is especially a problem in airway epithelia, a target for gene transfer in the genetic disease cystic fibrosis $(\mathrm{CF})^{1}(1)$. Several studies have shown that recombinant adenovirus vectors are able to transfer $\mathrm{CF}$ transmembrane conductance regulator (CFTR) cDNA and reporter genes to cultured airway epithelia and to the airways of animals (2-14). Moreover, studies

\footnotetext{
${ }^{\dagger}$ In memory of Dr. Al Fasbender.

Address correspondence to Michael J. Welsh, M.D., Howard Hughes Medical Institute, 500 EMRB, University of Iowa College of Medicine, Iowa City, IA 52242. Phone: 319-335-7619; FAX: 319-3357623; E-mail: mjwelsh@blue.weeg.uiowa.edu

Received for publication 5 January 1998 and accepted in revised form 22 April 1998.
}

J. Clin. Invest.

(C) The American Society for Clinical Investigation, Inc. 0021-9738/98/07/0184/10 \$2.00

Volume 102, Number 1, July 1998, 184-193

http://www.jci.org in humans have shown that adenovirus vectors can direct expression of CFTR and at least partially correct the defect in airway epithelial $\mathrm{Cl}^{-}$transport (15-19). However, when all the data are considered together, they suggest that the efficiency of gene transfer to differentiated, ciliated airway epithelia is low.

Adenovirus (Ad) interacts with cultured cell lines via adenovirus fiber binding to its cell surface receptor $(20,21)$ and binding of adenovirus penton base with $\alpha \gamma$ integrins (22). We found that infection of airway epithelia is inefficient because differentiated epithelia lack adenoviral fiber receptor activity on their apical surface (23). The lack of apical integrins may also limit gene transfer, although their absence seems to play a less important role than the lack of fiber receptors $(23,24)$. These limitations can be circumvented by incubating virus with the epithelium for a prolonged period of time (25). We also found that cationic molecules (poly-L-lysine [PLL] or cationic lipids) form a noncovalent complex with negatively charged adenovirus and associate with the negatively charged cell membrane. This increases cell binding via a non-fiber-dependent pathway and enhances adenovirus-mediated transgene expression (26). Arcasoy et al. (27) came to similar conclusions. In a related approach, Wickham et al. (28) found that inclusion of a polylysine tail at the $\mathrm{COOH}$-terminal end of fiber protein enhanced gene transfer to adenovirus-resistant cells.

Although complexes of cationic molecules and adenovirus enhanced gene transfer, there are limitations. First, previous studies have shown that cationic molecules can have direct cell toxicity; this is especially the case for cationic lipids (29-31). Moreover, intrapulmonary delivery of cationic lipids and DNA can generate toxic and inflammatory responses on their own (32). Second, delivery of adenovirus alone to the lung can generate an immune response $(10,33,34)$. When a cationic lipid is administered with adenovirus, the lipid might serve as an adjuvant, increasing the immune response to the coadministered adenovirus (35); in addition, PLL and cationic lipids can activate complement (36). Third, in earlier work we showed that complexes of adenovirus and cationic molecules enhanced gene transfer to airway epithelia in mouse nasal mucosa (26). However, in subsequent work we found that intrapulmonary delivery of adenovirus complexed with cationic lipids targeted the alveolar epithelium (our unpublished observations), whereas the airways are the intended target in $\mathrm{CF}$.

While studying complexes of adenovirus and PLL or cationic lipids, we found that they formed aggregates (26). This observation suggested the possibility that an aggregate or precipitate might itself facilitate infection. Therefore, we tested the hypothesis that inclusion of adenovirus in a precipitate

1. Abbreviations used in this paper: $\mathrm{Ad}$, adenovirus; $\mathrm{CaPi}$, calcium phosphate; CF, cystic fibrosis; CFTR, cystic fibrosis transmembrane conductance regulator; EMEM, Eagle's minimal essential media; IU, infectious units; PLL, poly-L-lysine. 
would enhance gene transfer to airway epithelia. We investigated calcium phosphate $(\mathrm{CaPi})$ because it readily forms a precipitate. CaPi precipitates have also been used for transfection of plasmid DNA into some cultured cell lines $(37,38)$. However, it is well known that DNA:CaPi precipitates are not effective in most primary cell cultures or in vivo (also see Fig. 6 below).

\section{Methods}

Cell culture. NIH-3T3 and COS-1 cells were cultured on 24-well plates (Corning, 25820) in DMEM (high glucose) supplemented with $10 \%$ FCS (Sigma Chemical Co., St. Louis, MO), $100 \mathrm{U} / \mathrm{ml}$ penicillin, and $100 \mu \mathrm{g} / \mathrm{ml}$ streptomycin (P/S). HeLa cells were cultured in Eagle's minimal essential media (Life Technologies, Inc., Gaithersburg, MD) supplemented with $10 \%$ FCS, $10 \mathrm{mM}$ nonessential amino acids (Sigma), $100 \mathrm{U} / \mathrm{ml}$ penicillin, and $100 \mu \mathrm{g} / \mathrm{ml}$ streptomycin. Cultured cell lines were infected 18-24 h after seeding when the cells were $\sim 70 \%$ confluent. Primary cultures of normal and CF human airway epithelia were isolated and grown as described previously $(25,39)$. The culture media consisted of a 1:1 mix of DMEM/Ham's F12, 5\% Ultraser G (Biosepra SA, Cedex, France), $100 \mathrm{U} / \mathrm{ml}$ penicillin, $100 \mu \mathrm{g} /$ $\mathrm{ml}$ streptomycin, $1 \%$ nonessential amino acids, and $0.12 \mathrm{U} / \mathrm{ml}$ insulin. Cells were seeded on Millicell polycarbonate filters (Millipore Corp., Bedford, MA). $24 \mathrm{~h}$ after seeding, the cells were switched to the airliquid interface and then grown with a dry apical surface. Epithelia were infected at least 2 wk after seeding; transgene expression was measured 2-4 d later.

Vectors and vector-related reagents. Recombinant adenovirus vectors expressing $\beta$-galactosidase, Ad $2 / \beta \mathrm{Gal}-2$, and CFTR, Ad2/CFTR16 , were prepared as described previously (25) by the University of Iowa Gene Transfer Vector Core at titers of $\sim 10^{10}$ infectious units $(\mathrm{IU}) / \mathrm{ml}$. Fiber knob protein was a gift of Dr. Paul Freimuth (Brookhaven National Laboratories, Upton, NY). In some studies, adenovirus was complexed with PLL (55 kD; Sigma) or the cationic lipid GL-67 (a gift of Drs. Seng Cheng and David Harris, Genzyme Corp., Cambridge, MA), as previously described (26). Neutralizing antibody (1401; Virostat, Portland, ME) or nonneutralizing antibody (mAb 8052; Chemicon International Inc., Temecula, CA) was applied to virus in some studies. A 1:100 dilution of antibody was incubated with $2 \times 10^{9}$ particles for $30 \mathrm{~min}$ at room temperature before formation of coprecipitates.

For most studies $\mathrm{CaPi}$ coprecipitates containing adenovirus were formed by placing $8 \times 10^{9}$ particles of recombinant adenovirus in $1 \mathrm{ml}$ of Eagle's minimal essential media (M-0268; Sigma), which contains $1.8 \mathrm{mM} \mathrm{Ca}^{2+}$ and $0.86 \mathrm{mM}$ Pi. Then an aliquot of a $2 \mathrm{M} \mathrm{CaCl}_{2}\left(\mathrm{CaCl}_{2}\right.$. $2 \mathrm{H}_{2} \mathrm{O}$, E1200; Promega, Madison, WI) solution was added to achieve the desired $\mathrm{Ca}^{2+}$ concentration. However, a wide range of adenovirus particles and concentrations of $\mathrm{Ca}^{2+}$ and $\mathrm{Pi}$ was used as described in the text and figure legends. The solution was mixed by vortex or gentle pipette tip aspiration. Note that the $\mathrm{Ca}^{2+}$ and $\mathrm{Pi}$ concentrations refer to total rather than free concentrations. Unless otherwise noted, the mixture was allowed to incubate for 20-30 min at room temperature. Then $250 \mu \mathrm{l}$ was applied to cells for $20 \mathrm{~min}$ followed by washing the surface to remove the complex.

To evaluate virus association with cells, adenovirus was labeled with the carbocyanine dye Cy3 (Amersham Inc., Arlington Heights, IL) using methods described to us by Drs. P.L. Leopold and R.G. Crystal (40). Cy3 was covalently conjugated to capsid proteins of Ad2/ $\beta$ Gal-2 by mixing $5 \mathrm{nmol}$ of Cy3 with $10^{12}$ particles of virus in $1.5 \mathrm{ml}$ of $\mathrm{Na}_{2} \mathrm{CO}_{3}, \mathrm{pH} 9.0$, for $2 \mathrm{~h}$ at $4^{\circ} \mathrm{C}$. The solution was subsequently transferred to a dialysis chamber (Slide-A-Lyzer, 10,000 mol wt cutoff; Pierce Chemical Co., Rockford, IL) and dialyzed against two

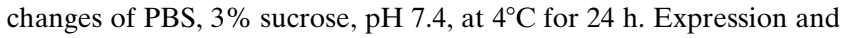
infection studies were performed immediately after dialysis of the conjugate. This labeling procedure decreased the IU/particle ratio by $5-35 \%$.
Evaluation of transgene expression and toxicity. $\beta$-galactosidase activity was measured $24 \mathrm{~h}$ after application of vector as described previously (26). X-gal staining of epithelia was as described previously (25). To evaluate transepithelial electrolyte transport, epithelia were mounted in modified Ussing chambers (25). Short-circuit current (Isc) was measured under baseline conditions, and after addition of amiloride $(10 \mu \mathrm{M})$, cAMP agonists $(10 \mu \mathrm{M}$ forskolin and $100 \mu \mathrm{M}$ IBMX), and bumetanide $100 \mu \mathrm{M}$. Individual experiments were performed using three sets of cells and all experiments were repeated at least three times. Statistical significance was evaluated using a paired or unpaired $t$ test.

Transmission electron microscopy. Ad:CaPi coprecipitates were processed for transmission electron microscopy using a negative stain technique. $15-\mu l$ drops of freshly prepared samples were placed on glow-discharged collodion/carbon-coated 400-mesh copper grids for $3 \mathrm{~min}$. The solution was wicked off with filter paper and replaced with $1 \%$ aqueous uranyl acetate for $30 \mathrm{~s}$. After removal of this solution, grids were allowed to dry and imaged in a Hitachi H-7000 transmission electron microscope.

Studies in mice. For in vivo analysis, we used 6-8-wk-old C57BL/6 mice (The Jackson Laboratory, Bar Harbor, ME). Mice were lightly anesthetized using a methoxyflurane chamber. Ad2/ $\beta$ Gal- $2\left(2 \times 10^{8}\right.$ $\mathrm{IU}, 5 \times 10^{9}$ particles) was administered alone or as Ad:CaPi coprecipitates intranasally in two $62.5-\mu \mathrm{l}$ instillations delivered $5 \mathrm{~min}$ apart. The experiment was performed twice with six animals in each group. $3 \mathrm{~d}$ after vector administration, animals were killed. PBS $(10 \mathrm{ml})$ was instilled into the right ventricle and then the lungs and heart were removed intact. The trachea was intubated and instilled at $10 \mathrm{~cm}$ of pressure with the following solutions in order: PBS, $4 \%$ paraformaldehyde and $0.2 \%$ glutaraldehyde, PBS, and finally X-gal reagent for an overnight incubation at room temperature. After photography, lungs were embedded in paraffin and serially sectioned. Lung sections for each condition $(n=3)$ were analyzed by counting all airways that were cut at a perpendicular angle. For each such airway, the airway diameter and number of blue cells was determined. The percentage of blue cells was calculated as: number of blue cells $\div$ (diameter $\times$ $\pi \div 4.9 \mu \mathrm{m})$. The average width of an airway cell $(4.9 \mu \mathrm{m})$ was determined in separate experiments using hematoxylin and eosin-stained sections and is in excellent agreement with earlier studies (41).

\section{Results}

Ad:CaPi coprecipitates enhance gene transfer to NIH 3 T3 cells. To learn whether incorporation of Ad2/ $/ \mathrm{Gal}-2$ in a precipitate would enhance adenovirus-mediated gene transfer, we initially studied $3 \mathrm{~T} 3$ cells, because they show little fiber receptor activity and are resistant to adenovirus infection (42). In these respects they resemble the apical surface of differentiated airway epithelia. We applied vector for only a short time (20 $\mathrm{min}$ ), then removed it, and measured transgene expression 24 h later. Fig. 1, $A$ and $B$, shows that when we increased $\mathrm{Ca}^{2+}$ and $\mathrm{Pi}$ concentrations during complex formation, $\beta$-galactosidase expression increased, reached a maximum, and then decreased. These data suggest that formation of an effective precipitate or aggregate required an optimal stoichiometry of $\mathrm{Ca}^{2+}$ to Pi. Since CaPi precipitation and CaPi-mediated plasmid transfection is $\mathrm{pH}$ dependent $(37,38)$, we asked what role $\mathrm{pH}$ would play in gene transfer by $\mathrm{Ad}: \mathrm{CaPi}$ coprecipitates. Fig. $1 C$ shows that when we attempted to form complexes at acidic $\mathrm{pH}$ (below $\mathrm{pH} 7$ ) there was little enhancement of gene transfer; an acidic $\mathrm{pH}$ has similar effects on $\mathrm{CaPi}$-mediated plasmid transfection $(37,38)$. As a control for the effect of $\mathrm{pH}$ on the virus, we infected HeLa cells with adenovirus alone that had been exposed to the same $\mathrm{pH}$ as the Ad:CaPi coprecipitates; we found no effect of $\mathrm{pH}$ on gene transfer (not shown). The 
time during which $\mathrm{Ca}^{2+}, \mathrm{Pi}$, and adenovirus complexes were incubated before they were applied to cells also influenced gene transfer. As the duration of the preincubation period increased, transfection efficiency increased and then decreased (Fig. $1 D$ ). We also saw a time-dependent effect on precipitate formation, light microscopy and visual inspection showed first the formation of fine precipitates when infection was maximal, and then with long duration preincubation periods, macro-precipitates formed and gene expression decreased. Future studies will be required to evaluate the size of the precipitate that correlates with the greatest enhancement of transgene expression. Fig. $1 E$ shows that when the amount of virus added during complex formation increased (without a change in volume, $\mathrm{Ca}^{2+}$, or $\mathrm{Pi}$ ), gene expression increased.

The increase in total transgene expression shown in Fig. 1 was paralleled by an increase in the percentage of 3T3 cells expressing transgene, after applying adenovirus alone for $20 \mathrm{~min}$, $3.5 \%$ of the cells stained blue $(n=607$ cells $)$ after staining for $\beta$-galactosidase, whereas with Ad:CaPi coprecipitates $99 \%$ of cells stained blue ( $n=800$ cells). Ad:CaPi coprecipitates also enhanced expression in other cells that are relatively resistant

A

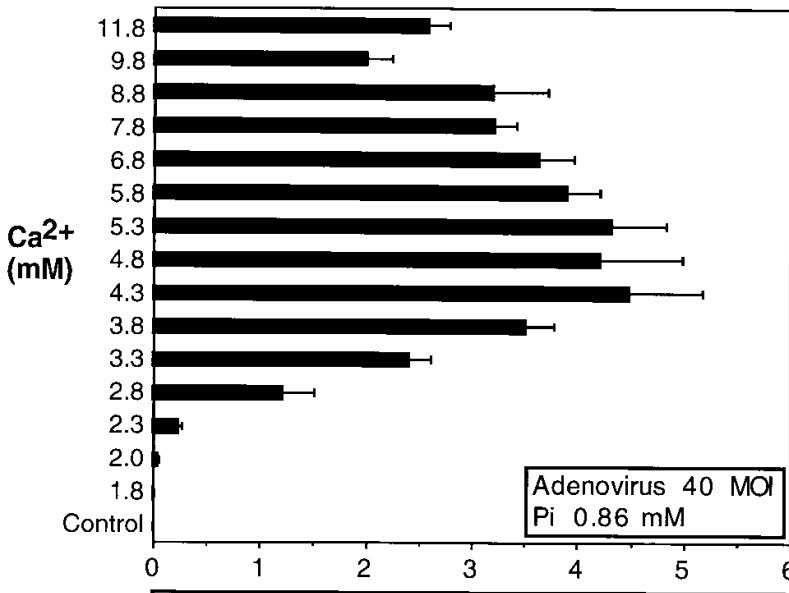

B

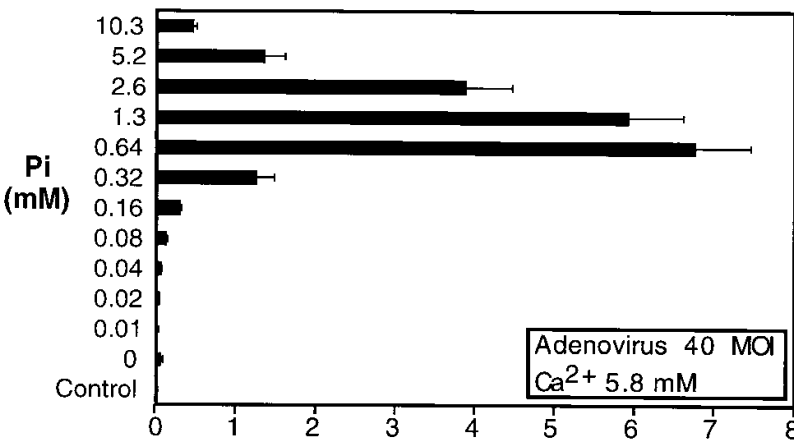

C

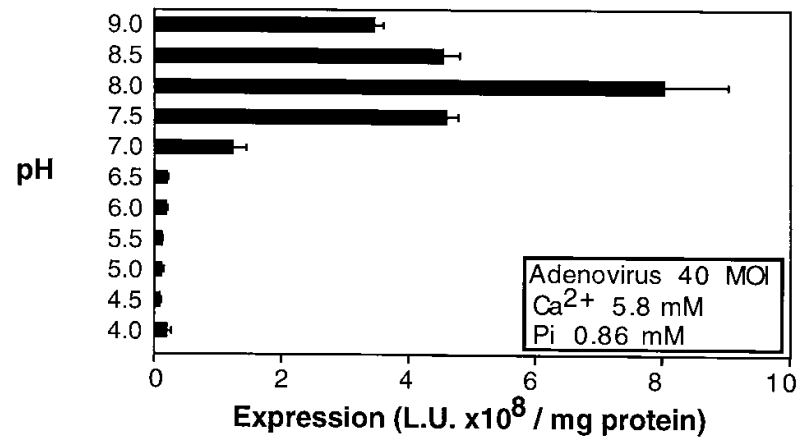

to adenovirus infection (9L gliosarcoma cells, a 130-fold increase compared with adenovirus alone, and primary cultures of human umbilical vein endothelial cells, a 150-fold increase) and in cells that are easily infected (HeLa cells, a 9-fold increase, and COS cells, a 12-fold increase).

After the Ad:CaPi coprecipitates were formed, they could be placed in serum-containing media and added to cells without loss of efficacy (Fig. $2 A$ ). This suggests that once the precipitate is generated, it is relatively stable. However, when we added serum to the solution before combining $\mathrm{Ca}^{2+}, \mathrm{Pi}$, and adenovirus, the enhancement in gene transfer was abolished (Fig. $2 \mathrm{~B}$ ). This result suggests that serum interferes with formation of the $\mathrm{Ad}: \mathrm{CaPi}$ coprecipitate. If we first formed $\mathrm{CaPi}$ precipitates and then separately applied them and the adenovirus to cells, there was little enhancement of expression (Fig. $2 C$ ). This result indicates that enhanced infection efficiency requires that adenovirus be included in the precipitate.

Ad:CaPi coprecipitates increase virus association with cells. We tested the hypothesis that the coprecipitate enhanced gene expression by increasing the amount of virus associated with cells. Fig. 3, $A-D$, shows representative photo-

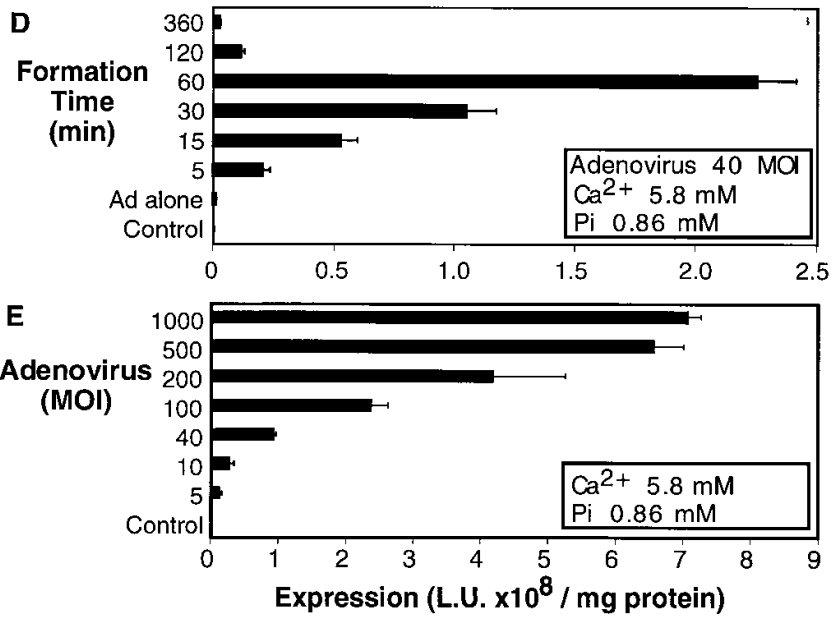

Figure 1. Gene transfer to NIH $3 \mathrm{~T} 3$ cells with Ad:CaPi coprecipitates. Standard conditions for these studies were a $\mathrm{Ca}^{2+}$ concentration of 5.8 $\mathrm{mM}$, Pi concentration of $0.86 \mathrm{mM}, \mathrm{pH} 7.4$, duration of complex formation before addition to cells of $15-30 \mathrm{~min}$, and 40 moi Ad2/ $\beta \mathrm{Gal}-2$.

Vector was applied to cells for $20 \mathrm{~min}$ in each case. In each panel one of these variables was tested over a range of values: $(A) \mathrm{Ca}^{2+}$ concentration; $(B)$ Pi concentration; $(C) \mathrm{pH}$ during complex formation; $(D)$ duration of complex formation before addition to cells; and $(E)$ moi of adenovirus. Data are $\beta$-galactosidase activity $24 \mathrm{~h}$ after vector addition. Each panel represents results from an experiment with $n=3$; each experiment was repeated at least twice. 
micrographs of NIH-3T3 cells treated with Cy3-labeled adenovirus alone $(A$ and $B$ ) or with Ad:CaPi coprecipitates ( $C$ and $D)$. When virus was incorporated into an $\mathrm{Ad}$ :CaPi coprecipitate there was more cell binding and/or uptake than when virus was applied alone. The increase in cell binding was paralleled by an increase in transgene expression by the $\mathrm{Cy} 3-$ labeled virus (Fig. $3 E$ ).

To learn whether the increase in association of virus with cells required uptake, we compared results obtained at 37 and $4^{\circ} \mathrm{C}$; incubation at $4^{\circ} \mathrm{C}$ will block endocytosis. Reduction in temperature had little effect on the amount of cell-associated fluorescence (Fig. $3 \mathrm{~F}$ ). These results suggest that inclusion of virus in a coprecipitate enhances expression by increasing the amount of virus bound to cells. We cannot exclude the possibility that it might also enhance endocytosis.

Gene transfer by Ad:CaPi coprecipitates does not depend on fiber receptor. The ability of Ad:CaPi coprecipitates to enhance gene transfer to NIH 3T3 cells, which express little fiber receptor, suggested that binding of adenovirus fiber to its cell surface receptor was not required. To test this hypothesis directly, we studied COS cells which are readily infected by adenovirus. Fig. $4 A$ shows that fiber knob protein inhibited transgene expression by adenovirus alone by $94 \%$. However, fiber knob protein had no appreciable effect on transgene expres-

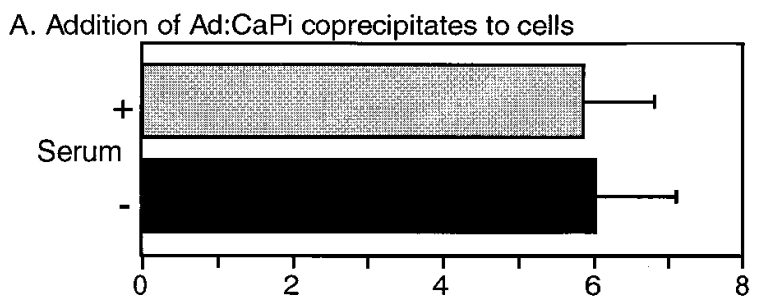

B. Formation of coprecipitate

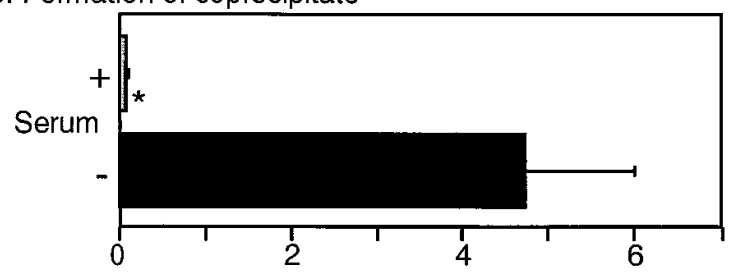

C. Addition of Ad:CaPi or Ad and CaPi to cells

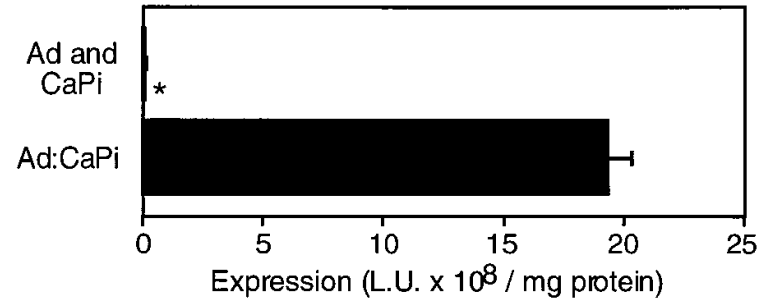

Figure 2. Effect of serum and separate addition of $\mathrm{CaPi}$ precipitates and adenovirus. In all experiments NIH 3T3 cells were treated with 40 moi adenovirus for $20 \mathrm{~min}$. (A) Ad:CaPi coprecipitates were formed in the absence of serum and then added to cells in the presence $(+)$ or absence $(-)$ of $10 \%$ FCS. $(B)$ Ad:CaPi coprecipitates were formed in the presence $(+)$ of $10 \%$ FCS, or $10 \%$ FCS was added after formation of the precipitate $(-)$. $(C)$ Ad:CaPi coprecipitates or adenovirus and $\mathrm{CaPi}$ precipitates were added separately to cells in the presence of $10 \%$ FCS. For $A-C$, the $\mathrm{Ca}^{2+}$ concentration was $5.8 \mathrm{mM}$, Pi concentration was $0.86 \mathrm{mM}$, and the precipitates were formed for 15-30 min. * $P<0.05$; data are from one experiment $(n=$ 3 ) and each experiment was repeated at least three times. sion by Ad:CaPi coprecipitates. These results indicate that adenovirus fiber is not required for the enhanced efficiency of infection.

When we disrupted viral proteins by heat inactivation, we inhibited transgene expression (Fig. $4 B$ ). We obtained similar results when, before complex formation, adenovirus was treated with a neutralizing antihexon antibody that presumably inhibits infection by interfering with steps subsequent to binding such as endosomal escape and traffic of viral DNA to the nucleus. Moreover, when we transfected cells with $\mathrm{CaPi}$ coprecipitates containing $2 \times 10^{9}$ plasmids encoding $\beta$-galactosidase, there was little expression compared with precipitates formed with $2 \times 10^{9}$ particles of Ad2/ $\beta$ Gal-2 (Fig. $4 \mathrm{~B}$ ). These data indicate that although fiber is not necessary for infection with Ad:CaPi coprecipitates, other adenoviral proteins are required to facilitate gene transfer and expression. These results also explain why $\mathrm{CaPi}$ precipitates that contain adenovirus produce much more transgene expression than those containing DNA alone (Fig. $4 \mathrm{~B}$ ).

We also formed precipitates with other anions and cations in a preliminary attempt to find a coprecipitate that might be more effective than $\mathrm{CaPi}$. For example, magnesium phosphate, manganese phosphate, cobalt phosphate, calcium carbonate, and calcium sulfide were capable of enhancing infection. However, they were not as effective as CaPi (data not shown). Monovalent cations such as sodium and potassium that do not form coprecipitates did not enhance infection.

Gene transfer with Ad:CaPi coprecipitates to human airway epithelia in vitro. To evaluate gene transfer to airway epithelia, we studied primary cultures of human airway epithelia grown at the air-liquid interface. Under these conditions, the epithelia differentiate and form a ciliated epithelium that is resistant to gene transfer by adenovirus and cationic lipid vectors (25, 43). Fig. $5 A$ shows that when vector was applied to the apical surface for a short exposure time (20 min), Ad:CaPi coprecipitates enhanced transgene expression.

The ability of Ad:CaPi coprecipitates to transfer CFTR cDNA to CF airway epithelia was tested by applying 50 moi Ad2/CFTR-16 for $20 \mathrm{~min}$. To assess CFTR $\mathrm{Cl}^{-}$current, we inhibited $\mathrm{Na}^{+}$current with amiloride $\left(10^{-5} \mathrm{M}\right)$, applied cAMP agonists, and then measured the current inhibited by bumetanide $(100 \mu \mathrm{M})$ applied to the basolateral surface. Fig. $5 B$ shows that untreated $\mathrm{CF}$ epithelia had no $\mathrm{Cl}^{-}$current. As a positive control, Ad2/CFTR-16 remained on the mucosal surface for $24 \mathrm{~h}$; this long incubation period allows significant transgene expression and transepithelial $\mathrm{Cl}^{-}$transport increases into the normal range (25). When we applied adenovirus alone for only $20 \mathrm{~min}$ there was little $\mathrm{Cl}^{-}$current, as previously reported $(23,25)$. However, when we applied Ad:CaPi coprecipitates for $20 \mathrm{~min}$, the $\mathrm{Cl}^{-}$current was at least as large as that obtained after a 24-h incubation with adenovirus alone. These data indicate that $\mathrm{Ad}: \mathrm{CaPi}$ coprecipitates are much more efficient than virus alone for transfer of CFTR cDNA to differentiated airway epithelia and generation of CFTR $\mathrm{Cl}^{-}$ current.

Ad:CaPi coprecipitate-mediated gene transfer to mouse airway epithelia in vivo. To investigate Ad:CaPi coprecipitates in vivo, we administered adenovirus to mouse lungs. We delivered Ad2/ $\beta$ Gal-2 $\left(2 \times 10^{8} \mathrm{IU}\right)$ by intranasal administration. This dose is lower than usually applied to obtain significant pulmonary gene transfer because we wished to learn whether delivery as a coprecipitate would enhance gene transfer. Fig. 

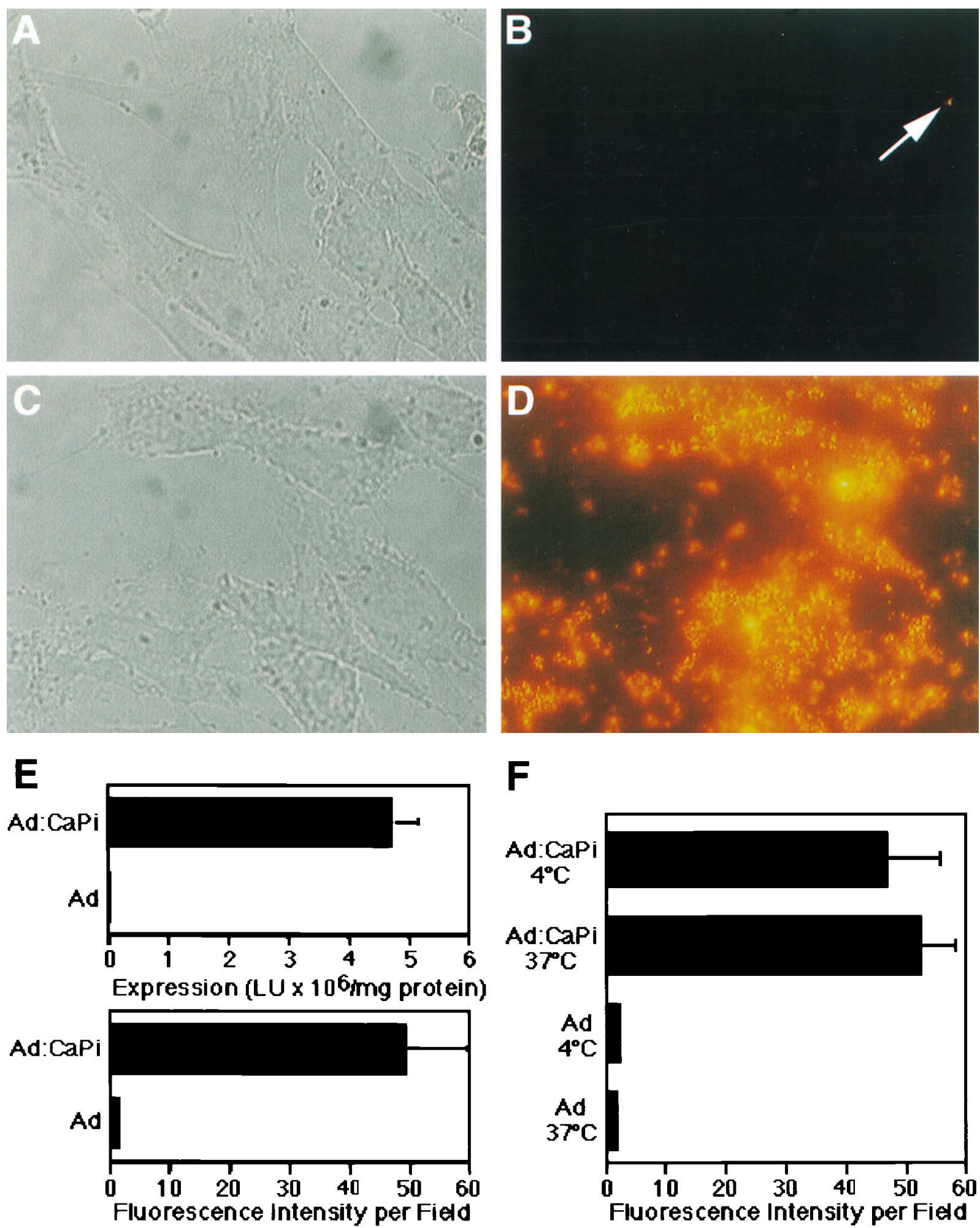

Figure 3. Effect of Ad:CaPi coprecipitates on adenovirus association with cells. To assess vector binding, NIH 3 T 3 cells were treated with $2 \times$ $10^{9}$ particles of Cy3-labeled Ad2/ $\beta$ Gal-2 for 60 min, rinsed with 3T3 media to remove unbound virus, and fixed with $4 \%$ paraformaldehyde. $A$ and $C$ show examples of light photomicrographs of cells also shown in $B$ and $D$, respectively. $C$ shows cells treated with Cy3:Ad alone and $D$ shows cells treated with Cy3:Ad:CaPi coprecipitates. The arrow in $B$ indicates labeled adenovirus. Ad:CaPi coprecipitates were formed with 5.8 $\mathrm{mM} \mathrm{Ca}^{2+}$ and $0.86 \mathrm{mM} \mathrm{Pi}$ and applied to cells at $37^{\circ} \mathrm{C}$. $E$ shows expression (top) and binding (bottom) from experiments shown in $A-D . n=3$ for expression and $n=5$ for binding data. $F$ shows binding at 4 and $37^{\circ} \mathrm{C}$. In both cases virus was placed on cells for 60 min and then removed by washing. $n=5$. 
$6 B$ shows a lung that received $A d 2 / \beta G a l-2$ alone. On gross examination, there was little evidence of staining and the lung appeared similar to lungs not treated with virus (Fig. $6 A$ ). In contrast, X-gal staining was readily apparent in the lungs treated with the same dose of virus delivered as Ad:CaPi coprecipitates (Fig. $6 \mathrm{C}$ ). Particularly striking was the pattern of $\mathrm{X}$-gal staining which traced the airways, rather than the parenchyma. Using direct inspection as in Fig. 6, we examined coprecipitates with a range of $\mathrm{Ca}^{2+}$ concentrations $(5.8,12,18$, and $36 \mathrm{mM}$ ) and found that precipitates that contained $12 \mathrm{mM}$ $\mathrm{Ca}^{2+}$ and $0.86 \mathrm{mM} \mathrm{Pi}$ were the most effective; those are the concentrations used in Fig. $6 C$.

Fig. 7 shows representative photomicrographs from lungs treated with adenovirus alone or $\mathrm{Ad}: \mathrm{CaPi}$ coprecipitates. In sections from lungs treated with adenovirus alone, there were a few blue-stained cells in airways and in the parenchyma (Fig.

A

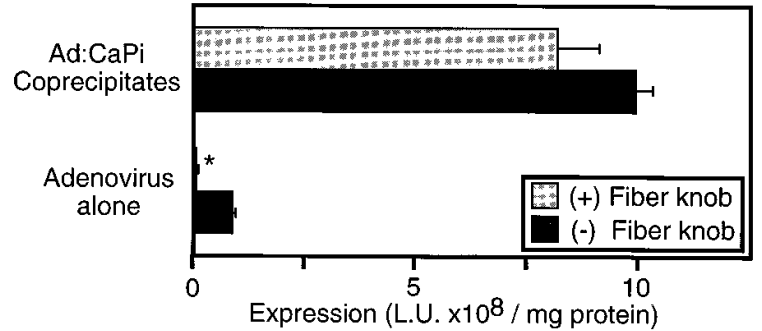

B

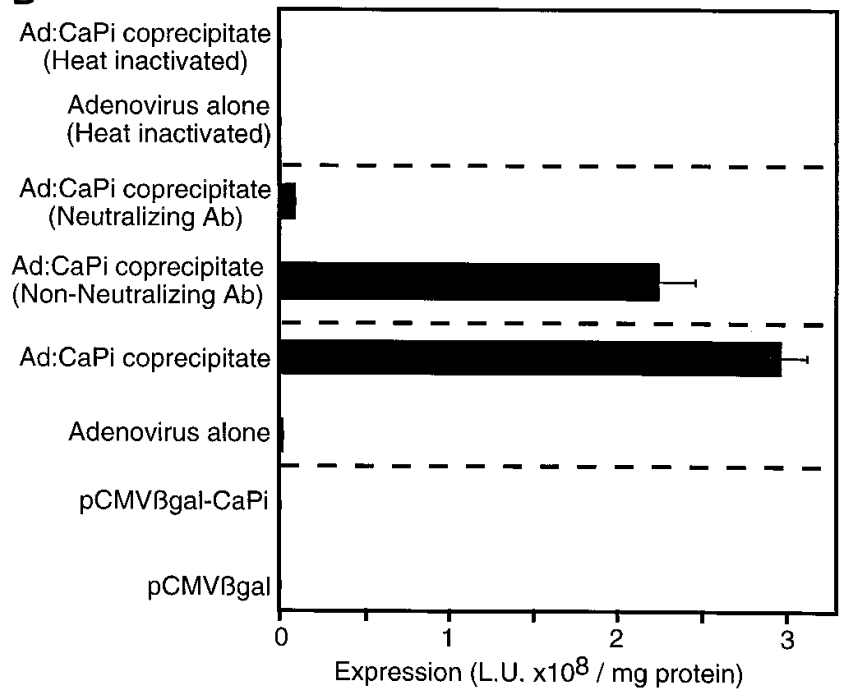

Figure 4. Effect of fiber knob protein, heat, and antibody inactivation on gene transfer by Ad:CaPi coprecipitates. $(A) \mathrm{COS}-1$ cells were studied because they express fiber receptor. Fiber knob $(0.7 \mu \mathrm{g} / \mathrm{ml})$ was added to cells for $10 \mathrm{~min}$ and then $\mathrm{Ad}: \mathrm{CaPi}$ coprecipitates were applied in the continued presence of fiber knob (shaded bars). Cells studied in absence of fiber knob are shown by black bars. $* P<0.05$. $(B)$ NIH 3 T3 cells were treated with all interventions for $20 \mathrm{~min}$, the vectors were then removed, and $\beta$-galactosidase activity was measured $24 \mathrm{~h}$ later. Virus was heat inactivated at $60^{\circ} \mathrm{C}$ for $30 \mathrm{~min}$ where indicated. Antibodies were incubated with virus for $30 \mathrm{~min}$ before coprecipitation. Plasmid DNA ( $\mathrm{p} \beta \mathrm{Gal}, 16.6 \mathrm{ng}$ ) was prepared in $\mathrm{CaPi}$ precipitates with the same conditions used for adenovirus. This amount of plasmid equals $\sim 2 \times 10^{9}$ plasmids. In both panels, cells treated with adenovirus received 40 moi $\left(2 \times 10^{9}\right.$ particles $)$ and Ad: $\mathrm{CaPi}$ coprecipitates were prepared with $5.8 \mathrm{mM} \mathrm{Ca}^{2+}$ and $0.86 \mathrm{mM} \mathrm{Pi}$ incubated for 15-30 min. Data are from one experiment $(n=3)$ and each experiment was repeated three times.
$7 \mathrm{~B}$ ). In contrast, Fig. $7 \mathrm{C}$ shows a field from a lung treated with Ad:CaPi coprecipitates; most small and medium-sized airways showed positively stained cells. Staining was predominantly in the airways with only rare positive cells in the parenchyma.

Fig. 8 shows a quantitative assessment of expression. We compared the percentage of blue-stained cells in airways of different diameters. In each airway region, more cells expressed the transgene after administration of Ad:CaPi coprecipitates than adenovirus alone. The greatest percentage of positive cells occurred in airways of $81-200 \mu \mathrm{m}$ in diameter. Of note, the actual percentage of cells transduced may be underestimated because of the limited sensitivity in detecting $\beta$-galactosidase activity with X-gal staining. Moreover, only a small number of CFTR $\mathrm{Cl}^{-}$channels is necessary for transepithelial $\mathrm{Cl}^{-}$transport $(1,44)$.

\section{Discussion}

The apical surface of airway epithelia forms a barrier that protects the internal environment from many agents in the external environment. This barrier has also proven to be a major impediment to the viral and nonviral gene transfer vectors currently being developed for CF airway epithelium. Our data show that gene transfer can be significantly enhanced by including adenovirus in a $\mathrm{CaPi}$ precipitate. We found enhanced

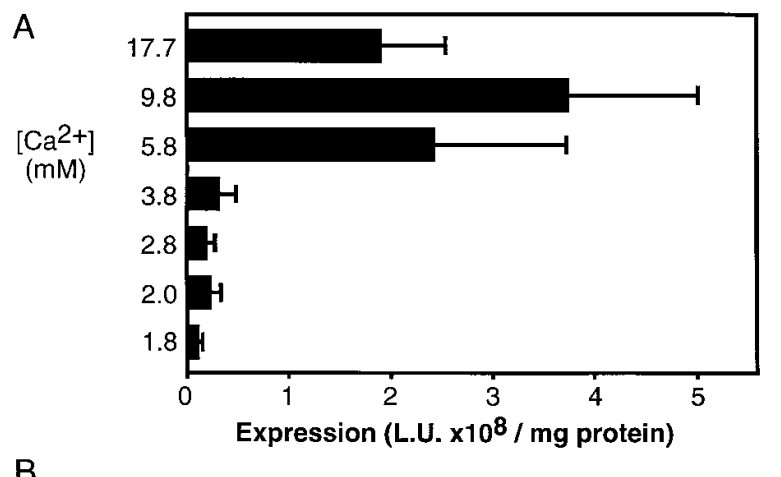

B

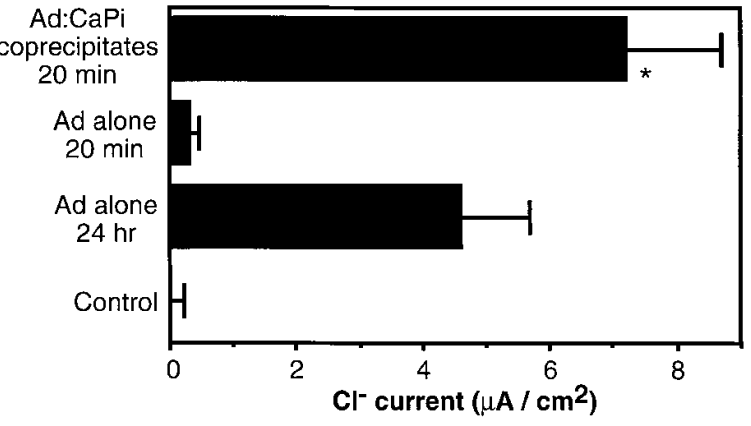

Figure 5. Expression of $\beta$-galactosidase and $\mathrm{CFTR} \mathrm{Cl}^{-}$current in normal and $\mathrm{CF}$ airway epithelia in vitro. Primary cultures of normal $(A)$ and $\mathrm{CF}(B)$ airway epithelia grown at the air-liquid interface were studied $14-20 \mathrm{~d}$ after seeding. Ad2/ $\beta$ Gal-2 or Ad2/CFTR-16 (50 moi) was applied to apical surface of epithelia for $20 \mathrm{~min}$ and then removed by washing. 3 or $4 \mathrm{~d}$ later, $\beta$-galactosidase activity $(A)$ or transepithelial $\mathrm{Cl}^{-}$current $(B)$ was measured as described in Methods. The $\mathrm{Ca}^{2+}$ concentration was varied as indicated in $A$ and was 5.8 $\mathrm{mM}$ in $B$. Pi concentration was $0.86 \mathrm{mM} . n=9$ in $A$ and 6 in $B .{ }^{*} P<$ 0.05 compared with adenovirus alone for $20 \mathrm{~min}$. 

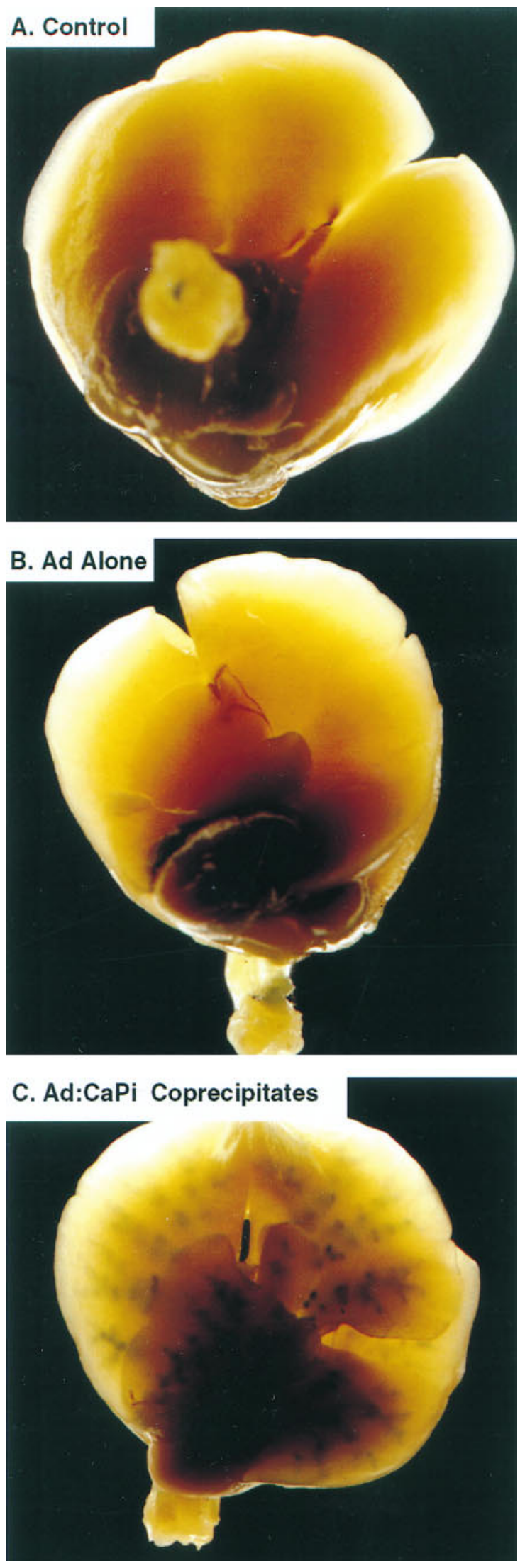

Figure 6. Ad:CaPi coprecipitates administered to mouse lung. Ad2/ $\beta \mathrm{Gal}-2\left(2 \times 10^{8} \mathrm{IU}\right)$ were administered as virus alone or as Ad:CaPi coprecipitates. $3 \mathrm{~d}$ later whole lungs were stained with $\mathrm{X}$-gal reagent. Photomicrographs are from animals treated with vehicle control $(A)$, expression in the NIH 3 T3 cell line, the 9L gliosarcoma cell line, primary cultures of human umbilical vein endothelial cells, primary cultures of differentiated human airway epithelia, and mouse airway epithelia in vivo. All of these are resistant to adenovirus infection, especially when virus is in contact with the cells for only a short time.

Compared with adenovirus alone, Ad:CaPi coprecipitates increased binding of virus to cells. Although we do not understand the mechanism involved, the increased binding was likely responsible for the increased transgene expression. This conclusion is consistent with several other observations. For example, binding can be specific through receptor targeting with bispecific antibodies $(45,46)$ or with modified sequences in penton base and fiber $(47,48)$. Binding can also be nonspecific with complexes of adenovirus with cationic lipids and polymers $(26,27)$ or with polylysine added to the $\mathrm{COOH}$ terminus of adenovirus fiber (28). Even prolonged incubation of virus with cells can markedly increase gene transfer to differentiated airway epithelia (25). Thus, an interaction between adenovirus fiber protein and its specific receptor on the cell surface (20) is not required for infection. Moreover, the fiberfiber receptor interaction may not always be optimal; we found that Ad:CaPi coprecipitates also increased expression in COS and HeLa cells which express fiber receptor and are easily infected. Our data also suggest that an interaction between viral penton base and cell surface integrins (49) is not required for infection because $\alpha \mathrm{v}$ integrins are not present on the apical membrane of airway epithelia $(23,24)$. Thus we speculate that almost any maneuver that increases the contact time between adenovirus and the cell will facilitate infection.

The results suggest a model by which Ad:CaPi coprecipitates affect gene transfer. First, they increase binding (Fig. 3), and then the cell internalizes Ad:CaPi coprecipitates into endosomes or phagosomes that differ from the usual receptormediated pathway used by adenovirus. We speculate that as the $\mathrm{pH}$ falls in the endosome, the $\mathrm{CaPi}$ precipitate will dissociate, releasing the virus. Viral proteins can then facilitate escape from the endosome and mediate traffic of viral DNA through the cytoplasm, entry into the nucleus, and transcription. It is also possible that $\mathrm{Ca}^{2+}$ released from endosomes may activate signal transduction pathways that facilitate gene transfer. In contrast to Ad:CaPi coprecipitates, gene transfer by plasmid DNA complexed with CaPi is inefficient in most cells; such a system lacks the viral proteins that are required to facilitate processes subsequent to binding. The same holds true for cationic lipid-mediated transfection of plasmid DNA $(43,50)$. Thus, use of a virus that encodes the transgene offers an advantage in terms of efficiency over vector systems in which plasmid DNA encodes the transgene.

In developing gene transfer for $\mathrm{CF}$, a key factor remains unknown; that is the percentage of cells that must be targeted to achieve clinical benefit. However, earlier studies suggest that gene transfer to $6-10 \%$ of cells is sufficient to correct the $\mathrm{CF}$ defect in transepithelial $\mathrm{Cl}^{-}$transport (51); and in preliminary studies we found that correction of $10-15 \%$ of airway cells is sufficient to completely correct the CF defect in transepithelial $\mathrm{Cl}^{-}$transport and correction of $5-20 \%$ of cells re-

adenovirus alone $(B)$, or Ad:CaPi coprecipitates $(C)$. Similar results were obtained with six animals in each group. Ad:CaPi coprecipitates were formed with $12 \mathrm{mM} \mathrm{Ca}^{2+}$ and $0.86 \mathrm{mM} \mathrm{Pi}$. 
verses the abnormally increased apical $\mathrm{NaCl}$ concentration in CF (52). The data with Ad:CaPi coprecipitates are encouraging in a number of respects. Several studies have delivered adenovirus alone to airway epithelia of CF patients in vivo. In most of those studies there was a significant, albeit small, correction of the CF electrophysiologic defect (15-19). In comparison to virus alone, $\mathrm{Ad}$ :CaPi coprecipitates produced a 25-fold greater increase in $\mathrm{Cl}^{-}$transport by differentiated $\mathrm{CF}$ airway epithelia (Fig. 5 B) and a 17-fold greater increase in the

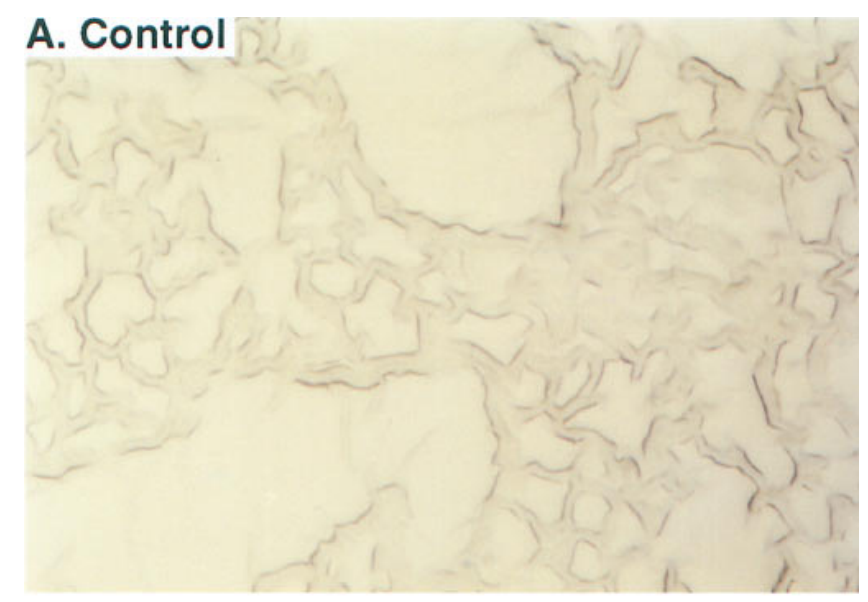

\section{B. Ad alone}

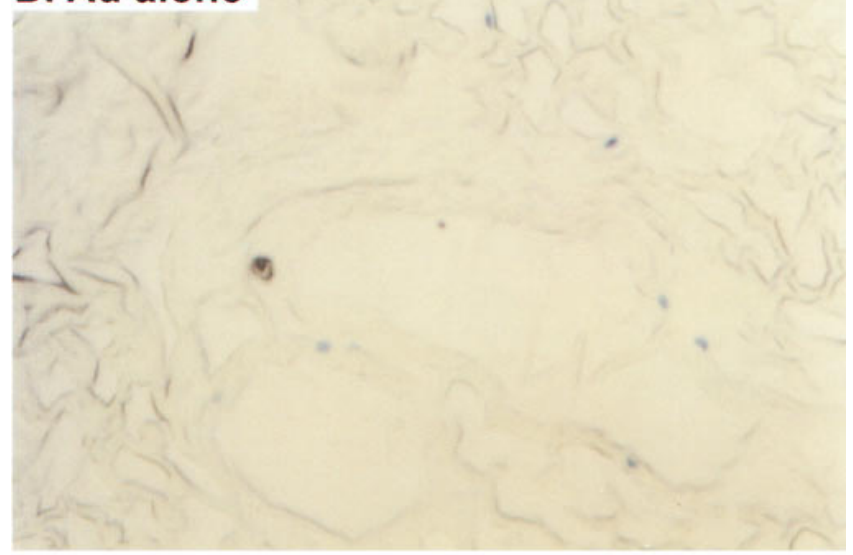

\section{Ad:CaPi Coprecipitates}

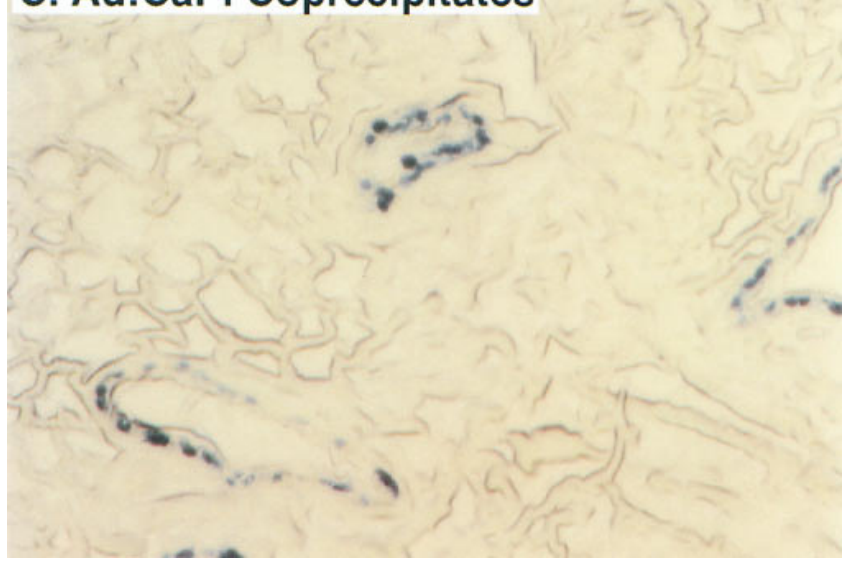

Figure 7. Photomicrographs from sections of mouse lungs treated as described in Fig. 6. (A) Control, $(B)$ adenovirus alone, and $(C)$ Ad: $\mathrm{CaPi}$ coprecipitates. percentage of cells expressing $\beta$-galactosidase in mouse conducting airways (81-200 $\mu \mathrm{m}$ diameter; Fig. 8). Thus, the data suggest that Ad:CaPi coprecipitates would markedly increase the degree of correction that has already been observed with adenovirus alone.

Use of Ad:CaPi coprecipitates for gene transfer has several potential advantages. First, for CF they have the distinct advantage that they produce expression in the airways rather than the alveoli, because airway epithelia are the site of disease in CF (1). Second, compared with cationic lipids, they show little direct cell toxicity; our preliminary results suggest they are also less toxic in vitro and in vivo. Third, they may be of value for use with other viral vectors such as adeno-associated virus, which can show limited efficiency in airway epithelia $(53,54)$. Fourth, they are simple and inexpensive to prepare; thus they could easily be used for a number of experimental applications in the research laboratory. They may be especially effective for cells that are resistant to infection. It is possible that they may also be of value for gene transfer in vivo to sites other than airway epithelia. Fifth, we would not expect that $\mathrm{Ca}^{2+}$ and $\mathrm{Pi}$ would have substantial toxicity; with our current formulation, we would deliver $\sim 200 \mathrm{mg} \mathrm{Ca}^{2+}$. We are not aware of studies evaluating $\mathrm{Ca}^{2+}$ delivery to the lung. However, for reference, $273 \mathrm{mg}$ of $\mathrm{Ca}^{2+}$ is administered intravenously for hypocalcemia and an oral Tums ${ }^{\mathrm{TM}}$ tablet has $200 \mathrm{mg}$ $\mathrm{Ca}^{2+}$. Ad:CaPi coprecipitates have the potential disadvantage that they do not contain a ligand that will target them to a specific cell or tissue type. However, in the airway this limitation can be overcome by delivery through the airway lumen so that the cells with which they first come in contact are the desired target for gene transfer.

The results suggest several experiments for the future. First, it will be important to examine the physical properties of the precipitate and to determine which are most important for gene transfer and expression. Such knowledge may allow the production of even more effective complexes. Second, it will be interesting to learn how Ad:CaPi coprecipitates enter cells. Previous work with DNA delivered by $\mathrm{CaPi}$ precipitates suggests that the complex is taken up by endocytosis/phagocytosis (55). The apical surface of differentiated airway epithelia in

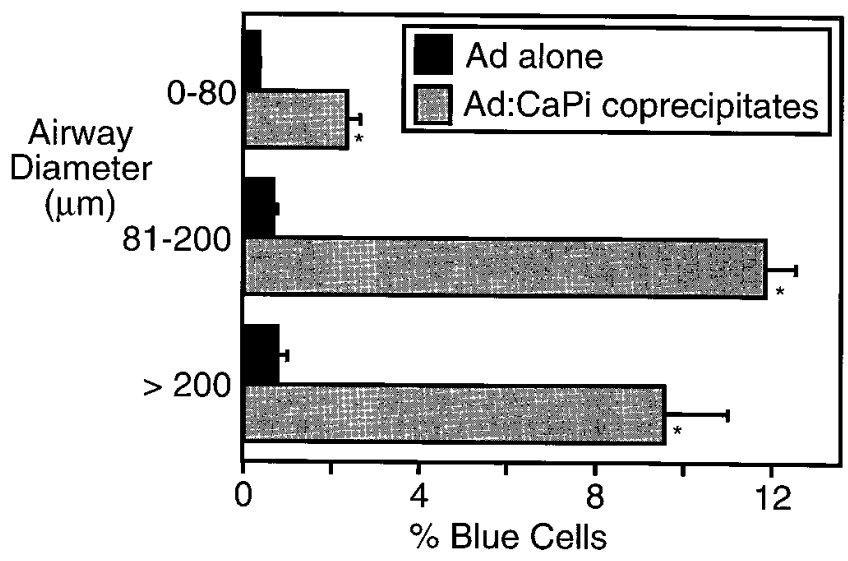

Figure 8. Gene transfer to mouse airway epithelium in vivo. Bluestained cells were counted in sections of lungs as described in Methods. The percentage of blue cells was determined for airways of the indicated sizes. Each bar indicates data from 50-200 airways. $* P<$ 0.05 . 
vitro and in vivo is not considered to be particularly active at endocytosis. However, a previous study showed that cationic ferritin administered to rat lungs appeared to enter epithelial cells of bronchioles (56). Third, our preliminary data suggest that precipitates produced with $\mathrm{CaPi}$ are more effective than those produced with other ions. This may relate to the physical properties of the precipitate. However, it might also be that $\mathrm{Ca}^{2+}$ itself may play some role in cell signaling that facilitates gene transfer.

These results are encouraging for developing $\mathrm{CF}$ gene transfer because use of $\mathrm{Ad}: \mathrm{CaPi}$ coprecipitates or related precipitates might lead to a more favorable therapeutic index. Our data suggest that gene transfer and expression can be achieved with a lower viral input dose than with adenovirus alone. This may decrease toxicity and attenuate the immune response while more effectively correcting the $\mathrm{CF}$ defect.

\section{Acknowledgments}

We thank Pary Weber, Phil Karp, Mike Seiler, Aurita Puga, and Theresa Mayhew for excellent assistance. We thank Drs. Philip L. Leopold and Ronald G. Crystal for sharing their method of labeling adenovirus with Cy3 before publication. We thank Drs. Sam Wadsworth and Alan Smith for the gift of Ad2/CFTR-16 and Ad2/ $\beta$ Gal-2, Drs. Seng Cheng and David Harris for the gift of GL-67, and Dr. Paul Freimuth for the gift of fiber knob protein.

We thank the University of Iowa Gene Transfer Vector Core (supported in part by the Roy J. Carver Charitable Trust), the Central Microscopy Research Facility, and the Diabetes and Endocrine Research Center (National Institutes of Health [NIH] grant DK25295) for help and support. This work was supported by a grant from the National Heart Lung and Blood Institute (HL-51670), the Cystic Fibrosis Foundation, and by the Howard Hughes Medical Institute (HHMI). J.H. Lee is supported by an NIH Research in Otolaryngology Fellowship (DIDCD 5732DC0040), J. Zabner is supported by the Carver Charitable Trust, and M.J. Welsh is an investigator of the HHMI.

\section{References}

1. Welsh, M.J., L.-C. Tsui, T.F. Boat, and A.L. Beaudet. 1995. Cystic fibrosis. In The Metabolic and Molecular Basis of Inherited Disease. C.R. Scriver, A.L. Beaudet, W.S. Sly, and D. Valle, editors. McGraw-Hill, Inc., New York. 3799-3876.

2. Rosenfeld, M.A., W. Siegfried, K. Yoshimura, K. Yoneyama, M. Fukayama, L.E. Stier, P.K. Paakko, P. Gilardi, L.D. Stratford-Perricaudet, M. Perricaudet, et al. 1991. Adenovirus-mediated transfer of a recombinant a1antitrypsin gene to the lung epithelium in vivo. Science. 252:431-434.

3. Rosenfeld, M.A., K. Yoshimura, B.C. Trapnell, K. Yoneyama, E.R. Rosenthal, W. Dalemans, M. Fukayama, J. Bargon, L.E. Stier, L. Stratford-Perricaudet, et al. 1992. In vivo transfer of the human cystic fibrosis transmembrane conductance regulator gene to the airway epithelium. Cell. 68:143-155.

4. Rich, D.P., L.A. Couture, L.M. Cardoza, V.M. Guiggio, D. Armentano, P.C. Espino, K. Hehir, M.J. Welsh, A.E. Smith, and R.J. Gregory. 1993. Development and analysis of recombinant adenoviruses for gene therapy of cystic fibrosis. Hum. Gene Ther. 4:461-476.

5. Engelhardt, J.F., Y. Yang, L.D. Stratford-Perricaudet, E.D. Allen, K. Kozarsky, M. Perricaudet, J.R. Yankaskas, and J.M. Wilson. 1993. Direct gene transfer of human CFTR into human bronchial epithelia of xenografts with E1deleted adenoviruses. Nat. Genet. 4:27-34.

6. Engelhardt, J.F., R.H. Simon, Y. Yang, M. Zepeda, S. Weber-Pendleton, B. Doranz, M. Grossman, and J.M. Wilson. 1993. Adenovirus-mediated transfer of the CFTR gene to lung of nonhuman primates: biological efficacy study. Hum. Gene Ther. 4:759-769.

7. Mastrangeli, A., C. Danel, M.A. Rosenfeld, L. Stratford-Perricaudet, M. Perricaudet, A. Pavirani, J.P. Lecocq, and R.G. Crystal. 1993. Diversity of airway epithelial cell targets for in vivo recombinant adenovirus-mediated gene transfer. J. Clin. Invest. 91:225-234.

8. O'Neal, W.K., and A.L. Beaudet. 1994. Somatic gene therapy for cystic fibrosis. Hum. Mol. Genet. 3:1497-1502.
9. Zabner, J., L.A. Couture, A.E. Smith, and M.J. Welsh. 1994. Correction of cAMP-stimulated fluid secretion in cystic fibrosis airway epithelia: efficiency of adenovirus-mediated gene transfer in vitro. Hum. Gene Ther. 5:585-593.

10. Zabner, J., D.M. Petersen, A.P. Puga, S.M. Graham, L.A. Couture, L.D. Keyes, M.J. Lukason, J.A. St. George, R.J. Gregory, A.E. Smith, and M.J Welsh. 1994. Safety and efficacy of repetitive adenovirus-mediated transfer of CFTR cDNA to airway epithelia of primates and cotton rats. Nat. Genet. 6:75-83.

11. Grubb, B.R., R.J. Pickles, H. Ye, J.R. Yankaskas, R.N. Vick, J.F. Engelhardt, J.M. Wilson, L.G. Johnson, and R.C. Boucher. 1994. Inefficient gene transfer by adenovirus vector to cystic fibrosis airway epithelia of mice and humans. Nature. 371:802-806.

12. Crystal, R.G. 1995. Transfer of genes to humans: early lessons and obstacles to success. Science. 270:404-410.

13. Johnson, L.G., S.E. Boyles, J. Wilson, and R.C. Boucher. 1995. Normalization of raised sodium absorption and raised calcium-mediated chloride secretion by adenovirus-mediated expression of cystic fibrosis transmembrane conductance regulator in primary human cystic fibrosis airway epithelial cells. $J$. Clin. Invest. 95:1377-1382.

14. Wilson, J.M. 1996. Adenovirus as gene-delivery vehicles. N. Engl. J. Med. 334:1185-1187.

15. Zabner, J., L.A. Couture, R.J. Gregory, S.M. Graham, A.E. Smith, and M.J. Welsh. 1993. Adenovirus-mediated gene transfer transiently corrects the chloride transport defect in nasal epithelia of patients with cystic fibrosis. Cell. 75:207-216.

16. Crystal, R.G., N.G. McElvaney, M.A. Rosenfeld, C.S. Chu, A. Mastrangeli, J.G. Hay, S.L. Brody, H.A. Jaffe, N.T. Eissa, and C. Danel. 1994. Administration of an adenovirus containing the human CFTR cDNA to the respiratory tract of individuals with cystic fibrosis. Nat. Genet. 8:42-51.

17. Hay, J.G., N.G. McElvaney, J. Herena, and R.G. Crystal. 1995. Modification of nasal epithelial potential differences of individuals with cystic fibrosis consequent to local administration of a normal CFTR cDNA adenovirus gene transfer vector. Hum. Gene Ther. 6:1487-1496.

18. Knowles, M.R., K.W. Hohneker, Z. Zhou, J.C. Olsen, T.L. Noah, P.C Hu, M.W. Leigh, J.F. Engelhardt, L.J. Edwards, K.R. Jones, et al. 1995. A controlled study of adenoviral-vector-mediated gene transfer in the nasal epithelium of patients with cystic fibrosis. N. Engl. J. Med. 333:823-831.

19. Zabner, J., B.W. Ramsey, D.P. Meeker, M.I. Aitken, R.P. Balfour, R.L. Gibson, J. Launspach, R.A. Moscicki, S.M. Richards, T.A. Standaert, et al. 1996. Repeat administration of an adenovirus vector encoding CFTR to the nasal epithelium of patients with cystic fibrosis. J. Clin. Invest. 97:1504-1511.

20. Bergelson, J.M., J.A. Cunningham, G. Droguett, E.A. Kurt-Jones, A. Krithivas, J.S. Hong, M.S. Horwitz, R.L. Crowell, and R.W. Finberg. 1997. Isolation of a common receptor for Coxsackie B viruses and adenoviruses 2 and 5 . Science. 275:1320-1323.

21. Mayr, G.A., and P. Freimuth. 1997. A single locus on human chromosome 21 directs the expression of a receptor for adenovirus type 2 in mouse A9 cells. J. Virol. 71:412-418.

22. Wickham, T.J., P. Mathias, D.A. Cheresh, and G.R. Nemerow. 1993. Integrins alpha $\mathrm{v}$ beta 3 and alpha $\mathrm{v}$ beta 5 promote adenovirus internalization but not virus attachment. Cell. 73:309-319.

23. Zabner, J., P. Freimuth, A. Puga, A. Fabrega, and M.J. Welsh. 1997. Lack of high affinity fiber receptor activity explains the resistance of ciliated airway epithelia to adenovirus infection. J. Clin. Invest. 100:1144-1149.

24. Goldman, M.J., and J.M. Wilson. 1995. Expression of alpha v beta 5 integrin is necessary for efficient adenovirus-mediated gene transfer in the human airway. J. Virol. 69:5951-5958.

25. Zabner, J., B.G. Zeiher, E. Friedman, and M.J. Welsh. 1996. Adenovirus-mediated gene transfer to ciliated airway epithelia requires prolonged incubation time. J. Virol. 70:6994-7003.

26. Fasbender, A., J. Zabner, M. Chillon, T.O. Moninger, A.P. Puga, B.L. Davidson, and M.J. Welsh. 1997. Complexes of adenovirus with polycationic polymers and cationic lipids increase the efficiency of gene transfer in vitro and in vivo. J. Biol. Chem. 272:6479-6489.

27. Arcasoy, S.M., J.D. Latoche, M. Gondor, B.R. Pitt, and J.M. Pilewski. 1997. Polycations increase the efficiency of adenovirus-mediated gene transfer to epithelial and endothelial cells in vitro. Gene Ther. 4:32-38.

28. Wickham, T.J., P.W. Roelvink, D.E. Brough, and I. Kovesdi. 1996. Adenovirus targeted to heparan-containing receptors increases its gene delivery efficiency to multiple cell types. Nature Biotech. 14:1570-1573.

29. Yagi, K., H. Noda, M. Kurono, and N. Oshishi. 1993. Efficient gene transfer with less cytotoxicity by means of cationic multilamellar liposomes. Biochem. Biophys. Res. Commun. 196:1042-1048.

30. Fasbender, A.J., J. Zabner, and M.J. Welsh. 1995. Optimization of cationic lipid-mediated gene transfer to airway epithelia. Am. J. Physiol. 269:L45-L51.

31. Cortesi, R., E. Esposito, E. Menegatti, R. Gambari, and C. Nastruzzi. 1996. Effect of cationic liposome composition on in vitro cytotoxicity and protective effect on carried DNA. Int. J. Pharmaceut. 139:69-78.

32. Scheule, R.K., J.A. St. George, R.G. Bagley, J. Marshall, J.M. Kaplan, G.Y. Akita, K.X. Wang, E.R. Lee, D.J. Harris, C. Jiang, et al. 1997. Basis of pulmonary toxicity associated with cationic lipid-mediated gene transfer to the mammalian lung. Hum. Gene Ther. 8:689-707.

33. Yei, S., N. Mittereder, K. Tang, C. O'Sullivan, and B.C. Trapnell. 1994. 
Adenovirus-mediated gene transfer for cystic fibrosis: quantitative evaluation of repeated in vivo vector administration to the lung. Gene Ther. 1:192-200.

34. Yang, Y., F.A. Nunes, K. Berencsi, E.E. Furth, E. Gonczol, and J.M. Wilson. 1994. Cellular immunity to viral antigens limits E1-deleted adenoviruses for gene therapy. Proc. Natl. Acad. Sci. USA. 91:4407-4411.

35. Hunter, R., F. Strickland, and F. Kezdy. 1981. The adjuvant activity of nonionic block polymer surfactants. I. The role of hydrophile-kipophile balance. J. Immunol. 127:1244-1250.

36. Plank, C., K. Mechtler, F.C. Szoka, and E. Wagner. 1996. Activation of the complement system by synthetic DNA complexes: a potential barrier for intravenous gene delivery. Hum. Gene Ther. 7:1441-1450.

37. Chen, C., and H. Okayama. 1988. Calcium phosphate-mediated gene transfer: a highly efficient system for stably transforming cells with plasmid DNA. Biotechniques. 6:632-638.

38. Chen, C., and H. Okayama. 1987. High-efficiency transformation of mammalian cells by plasmid DNA. Mol. Cell. Biol. 7:2745-2752.

39. Smith, J.J., S.M. Travis, E.P. Greenberg, and M.J. Welsh. 1996. Cystic fibrosis airway epithelia fail to kill bacteria because of abnormal airway surface fluid. Cell. 85:229-236.

40. Leopold, P.L., B. Ferris, I. Grinberg, S. Worgall, N.R. Hackett, and R.G. Crystal. 1998. Fluorescent virions: dynamic tracking of the pathway of adenoviral gene transfer vectors in living cells. Hum. Gene Ther. 9:367-378.

41. Mariassy, A.T. 1992. Epithelial cells of trachea and bronchi. In Comparative Biology of the Normal Lung. R.A. Parent, editor. CRC Press, Boca Raton. $63-76$

42. Seth, P., M. Rosenfeld, J. Higginbotham, and R.G. Crystal. 1994. Mechanism of enhancement of DNA expression consequent to cointernalization of a replication-deficient adenovirus and unmodified plasmid DNA. J. Virol. 68: 933-940.

43. Fasbender, A., J. Zabner, B.G. Zeiher, and M.J. Welsh. 1997. A low rate of cell proliferation and reduced DNA uptake limit cationic lipid-mediated gene transfer to primary cultures of ciliated airway epithelia. Gene Ther. 4: 1173-1180.

44. Trapnell, B.C., C.S. Chu, P.K. Paakko, T.C. Banks, K. Yoshimura, V.J. Ferrans, M.S. Chernick, and R.G. Crystal. 1991. Expression of the cystic fibrosis transmembrane conductance regulator gene in the respiratory tract of normal individuals and individuals with cystic fibrosis. Proc. Natl. Acad. Sci. USA. 88: $6565-6569$.

45. Wickham, T.J., D.M. Segal, P.W. Roelvink, M.E. Carrion, A. Lizonova,
G.M. Lee, and I. Kovesdi. 1996. Targeted adenovirus gene transfer to endothelial and smooth muscle cells by using bispecific antibodies. J. Virol. 70:68316838 .

46. Douglas, J.T., B.E. Rogers, M.E. Rosenfeld, S.I. Michael, M. Feng, and D.T. Curiel. 1996. Targeted gene delivery by tropism-modified adenoviral vectors. Nature Biotech. 14:1574-1578.

47. Wickham, T.J., M.E. Carrion, and I. Kovesdi. 1996. Targeting of adenovirus penton base to new receptors through replacement of its RGD motif with other receptor-specific peptide motifs. Gene Ther. 2:750-756.

48. Krasnykh, V.N., G.V. Mikheeva, J.T. Douglas, and D.T. Curiel. 1996. Generation of recombinant adenovirus vectors with modified fibers for altering viral tropism. J. Virol. 70:6839-6846.

49. Wickham, T.J., E.J. Filardo, D.A. Cheresh, and G.R. Nemerow. 1994. Integrin alpha v beta 5 selectively promotes adenovirus mediated cell membrane permeabilization. J. Cell Biol. 127:257-264.

50. Zabner, J., A.J. Fasbender, T. Moninger, K.A. Poellinger, and M.J. Welsh. 1995. Cellular and molecular barriers to gene transfer by a cationic lipid. J. Biol. Chem. 270:18997-19007.

51. Johnson, L.G., J.C. Olsen, B. Sarkadi, K.L. Moore, R. Swanstrom, and R.C. Boucher. 1992. Efficiency of gene transfer for restoration of normal airway epithelial function in cystic fibrosis. Nat. Genet. 2:21-25.

52. Zabner, J., J. Smith, T. Grunst, and M.J. Welsh. 1997. Correction of the CF bacterial killing defect can be achieved by targeting a fraction of the airway epithelial cells. Pediatr. Pulmonol. Suppl. 14:284.

53. Flotte, T.R., S.A. Afione, C. Conrad, S.A. McGrath, R. Solow, H. Oka, P.L. Zeitlin, W.B. Guggino, and B.J. Carter. 1993. Stable in vivo expression of the cystic fibrosis transmembrane conductance regulator with an adeno-associated virus vector. Proc. Natl. Acad. Sci. USA. 90:10613-10617.

54. Halbert, C.L., T.A. Standaert, M.L. Aitken, I.E. Alexander, D.W. Rus sell, and A.D. Miller. 1997. Transduction by adeno-associated virus vectors in the rabbit airway: efficiency, persistence, and readministration. J. Virol. 71: 5932-5941.

55. Lyoter, A., G. Scangos, D. Juricek, D. Keene, and F.H. Ruddle. 1982 Mechanisms of DNA entry into mammalian cells. II. Phagocytosis of calcium phosphate DNA co-precipitate visualized by electron microscopy. Exp. Cell Res. 139:223-234

56. Ito, T., H. Kitamura, Y. Inayama, A. Nozawa, and M. Kanisawa. 1992 Uptake and intracellular transport of cationic ferritin in the bronchiolar and alveolar epithelia of the rat. Cell Tissue Res. 268:335-340. 